\title{
Innovative Thinking on the Education of Contemporary Chinese Architectural History
}

\author{
Xiangrui Xiong \\ College of Architecture \\ Xi'an University of Architecture and Technology \\ Xi'an, China \\ e-mail :1445938729@qq.com
}

\author{
Haozhong Yang \\ College of Architecture \\ Xi'an University of Architecture and Technology \\ Xi'an, China \\ e-mail :1350108760@qq.com
}

\author{
Ying Zhang \\ College of Architecture \\ Xi'an University of Architecture and Technology \\ Xi'an, China \\ e-mail :sbt920918@sina.com
}

\begin{abstract}
Architecture history education faces with challenges brought by the overall environmental changes in architectural education, tide cultural shock, student personality changes in the new era. In this context, we should rethink the educational idea, methods and objects, and seek innovations according to the characteristics of the times and the students. In the teaching process, we need to analyze the shortcomings of the traditional architectural history education, and on this basis to redefine the scope of architectural history education. We will improve the efficiency of interaction between teachers and students through the introduction of advanced teaching media, and encourage autonomous learning in students and diversity of accomplishments in the use of adaptable assessment model, so that the education of contemporary architecture history possesses a strong adaptability in the ever-changing environment.
\end{abstract}

Keywords-Architectural history; education; challenge; innovative approach

\section{INTRODUCTION}

Education is the important activity of the development of human civilization, and any discipline construction and knowledge acquisition are inseparable to educational activities which, in general, consist of educational purposes, educational objects, educational content, educational methods and other aspects ${ }^{[1]}$. As an ancient discipline, architecture has involved knowledge of technology, art, humanities and other fields in the long-term evolution, so the building of architectural education system is a crossintegration process involved multiple disciplines, among which the architecture history is the narrative of architecture development. In the long history of the architecture, a large number of ideas and theories that promote the development of architecture have been delivered. The learning of architecture is often from the study of architectural history, during which the perceptions of architectural design, architectural culture, architectural development are gradually accumulated. Even in today's highly developed society and economy, the architectural ideas and theory still need to be drawn from the architectural history. In the globalization of the construction market, the innovative cultivation of the personal quality of the architect is the core proposition of contemporary architectural education. In terms of the construction market in China, the cultural foundation and Independent thinking has become an important competitive capital in the pursuit of regional and cultural propositions. Only when one can tease out and inherit the architectural context, can he get rid of the limitations of the times. This also indicates the importance of the history teaching in the architectural education system. In the new era, facing with new challenges and opportunities, we also need to cultivate the targeted thinking and make innovations in architectural history education, in order to cultivate energetic architects adaptable to social trends.

\section{NEW CHALLENGES FOR ARCHITECTURE HISTORY EDUCATION IN NEW PERIOD}

Amid the common prosperity of global economy, science and technology have led the development of the times, and the development of architecture has gradually biased towards the construction technology, computer technology, energy-saving technologies and other natural sciences, while the learning and research of architectural history are at the attached position, and even spread as a fast-food education in the teachers and students. In view of this phenomenon, we have to face up to the challenges that the architectural history education encountered in the new era, and the affected groups engaged in the education are forced to carefully consider the current dilemma ${ }^{[2]}$.

\section{A. Overall environmental changes in architectural education}

Although China's architecture has a long history, the architectural education came up late, taking the actual 
construction projects working as the goal in the past few decades. In the teaching of history and theories of architecture, China has just opened the vision of western architectural education. Some senior masters have made significant groundbreaking works in the education and research of architecture history. They are Professor Chen Zhihua of Tsinghua University, Professor Luo Xiaowei of Tongji University, Professor Liu Xianjue of Southeast University, Professor Zhang Sizan of Xi'an University of Architecture and Technology and others. Later on, students took over their works and continued to extend the scope of the history of architecture in China's architecture education. At that time, a large number of historical materials of architecture and relevant information of western famous architects have been introduced to China, so the education mainly falls on the translation of literature and case studies with teachers and students closely interacted with each other. Students who are major in architecture also attach great importance to the learning of architecture history. The content of textbook is compiled by chronicling so as to make it easy to understand. However, in recent years, with internationalization and colorful educational resources, the overall environment of architectural education has undergone great changes. There are frequent interactions between Chinese and foreigners in architecture. Architectural thinking and theories have become diversified, causing students inactive to accept traditional teaching content and style, but they intend to follow the pace of popular architects to early take part in the architectural program. In this way, teaching breaks up with learning, moreover, students and teachers are not closely communicating. The development of architecture discipline exposes architectural history education to challenges in the new architectural education environment ${ }^{[3]}$.

\section{B. Tide Culture Shock}

With free choice of learning objects and goals, architecture learning is never confined to a single pattern, but it develops appropriate educational activities in line with the specific cultural environment and social needs. Economic prosperity has brought cultural prosperity. The trend of culture is the theme of an era. Today's culture spread at a high speed by the development of science and technology and a wide range of exchanges. In such an environment that history is affected by fashion culture, students would rather enjoy the visual impact brought by the science fiction films than read the boring historical literature. As urban consumption culture becomes the main current today, food, clothing, music, tourism and other cultural activities are launched in various forms, which are much more attractive more than historical and cultural events. Whereas the rise and development of these tide culture have much to do with architecture. The learning of the architecture history is based mainly on architectural culture knowledge, and partly on other cultures that illustrate the culture events in architecture history to master the building knowledge. However, under the impact of the tide culture, the master-subordinate relationship between the architectural history and culture and other cultures have changed. The fact that students are more keen to think about other unrelated aspects of the building and ignore the study of architectural history poses a challenge to architectural history education in the new era of culture.

\section{Students personality differences}

Since students are the main body of architectural education activities, their inherent characteristics have exerted great influence on contemporary architecture history education ${ }^{[4]}$. Most of the contemporary architectural students are born between 1990 and 2000 with distinctive personality and strong ability to acquire information. In the same group, each student retains different learning styles and attitudes towards architecture history, so the final learning effect is also different. We need to adjust the educational goals and methods to maximize the adaptability, as the traditional lecturing between teachers and students is not feasible to conduct the education of architecture history. In addition, one obvious feature of this generation is that they are hard to focus attention to complete efficiently the teaching requirements, for example, they prefer graphics to text reading, thus lacking patience to read a literature or a monograph. This has caused students' study of the architecture history always floating on the surface without absorbing ideological nutrition. It is also impossible to sum up their point of view from the historical literature or become critical thinking, which is a big problem in the education of contemporary architecture history.

\section{NEW REQUIREMENTS FOR ARCHITECTURAL HISTORY EDUCATION IN THE NEW PERIOD}

In a new era with so developed human civilization, architectural history education faces all sorts of difficulties and challenges. However, in front of these pressures, architectural history education also needs innovation to cope with the new requests brought by the change of architectural education system $^{[5]}$.

\section{A. Emphasize pluralism and openness}

Since reform and opening up, foreign modernism architectural thought and works of some of the leading architects after modernism have produced an important impact in China. At the same time a large number of overseas architects enter the domestic construction market, bringing enlightenment and stimulation on thoughts and design technique for young architecture students and local architects. The ideological blend of cross-cultural communication and cross-regional practice requires architectural history education to cope with the new requirement on the basis of traditional education mode. With architecture market going towards pluralism and opening, architectural education also needs to go towards pluralism and opening. As the production basis of architectural thought, the education reform of architectural history also has to go towards pluralism and opening. 
Currently domestic advanced architectural education focuses mainly on several key colleges and universities. These colleges emphasize cooperation and exchange with international famous colleges and universities. At the same time, they also combine with domestic actual problems, and greatly promote the pluralism and opening of education with the education mode of combining teaching, scientific research and practice into one, which also provides thinking for teaching development of other architecture schools. On the other hand, the current domestic construction perspective focuses on regionalism, traditional villages, heritage protection, the practice basis of which is the digging and studying of their related history knowledge. Therefore, in the face of practical problems, architectural history education still requires multiple and open education view and education framework, to accept new knowledge and local characteristics, and tolerate different thinking perspectives and critical inclination, enhancing the value of historical theory research at the contemporary.

\section{B. Focus on both history and theory, developmrnt theory with history}

The development of the discipline can't just stay on the summary and thinking on history. It also needs to explore the unknown knowledge, from fact analysis to experimental research. Therefore, while analyzing historical facts, the teaching and scientific research of architectural history should also form the theoretical connection between social reality and subject introduction. In architectural history education, there has to be written knowledge between teachers and students as basis. Through general history study and case study, with the parallel of teacher guidance and student divergent thinking as education goal, train students to have prospective thinking of discipline development and existing problems at the contemporary and in the future with historical information. The education requirement of focusing on both history and theory, and developing theory with history, is based on the practical requirement of discipline knowledge, and train students to find social problems with their own professional accumulation and try to solve the problems from different possible perspectives. This is the essential demands of architectural history study, and also the essential value of architectural theory derived from architectural history study. Although in the short period of teaching, it is difficult to let students reach this standard, at least it can inspire students to understand the value of learning architectural history at the contemporary, and autonomously find cutting-edge knowledge of architecture.

\section{The teaching method dealing with the characteristics of students}

We have analyzed the dilemma of contemporary architecture history education when facing a new generation of target students above, so contemporary teaching methods must adapt to the characteristics of students. The traditional education method of architectural history is mainly that teachers explain the professional knowledge they have accumulated to students by combining textbooks, and then ask students to complete corresponding course assignments and book reading. In the face of contemporary post-90s students, this procedural education method is inefficient. The educational target with characteristics of impetuous, novelty, fashion and having diverse learning methods, forces the education mode to adapt to these characteristics, so as to make characteristics change of students and the change of teaching method remain in a relative tacit and efficient state. Only in this way can we ensure that architectural history education will not fall behind in the new era. Innovation and seeking change is always the key to the success of education. It is a response to the era and the basic attitude towards the development of discipline.

\section{INNOVATION THINKING OF ARCHITECTURAL HISTORY EDUCATION}

The traditional teaching mode focuses on the dissemination of knowledge, emphasizes on the interpretation and imparting of knowledge points, and pays attention to students' acceptance, memory and mastery of knowledge points ${ }^{[6]}$. Learning in this teaching mode is a one-way thinking activity of students, and it is easy to fatigue the teaching and learning process from information source to information processing (Table I). The study in this paper is based on the strain thinking, and believes that architectural history education needs to be innovated from the three aspects of category positioning, teaching media and assessment mode.

\section{TABLE I. TRADITIONAL LEARNING PROCESS OF ARCHITECTURAL HISTORY EDUCATION}

\begin{tabular}{|l|l|l|l|l|}
\hline $\begin{array}{l}\text { Abstract } \\
\text { knowledge }\end{array}$ & $\rightarrow$ & $\begin{array}{l}\text { The teaching and } \\
\text { memory of knowledge } \\
\text { points }\end{array}$ & $\rightarrow$ & $\begin{array}{l}\text { Examinations } \\
\text { and assessments }\end{array}$ \\
\cline { 1 - 1 } $\begin{array}{l}\text { Information } \\
\text { source }\end{array}$ & $\begin{array}{l}\text { Cognitive processing of } \\
\text { students }\end{array}$ & $\begin{array}{l}\text { Leaning gain } \\
\text { and feedback }\end{array}$ \\
\hline
\end{tabular}

\section{A. The category positioning of architectural history education}

In the past, the main debate on architectural history education in domestic has focused on general history education or professional education. General history education emphasizes that the architectural history, as the basic literacy of architectural learning and historical and cultural knowledge, should become the knowledge that students must know and generally acquire. The fundamental purpose of general history education is to let people in the building industry who will be engaged in the study of architectural history or non-architectural history to obtain commonsense knowledge and have the most basic judgment in identifying architectural features. Professional education emphasizes the architectural history is a necessary branch of architectural discipline, and thoroughly study knowledge of the specific space and time included in architectural history from the three aspects of perspective of history, theory on history and historical event. The purpose of professional education is to cultivate the 
thinking logic to understand and design architecture, and to explore the possibility of the future from historical research. Based on the current architectural history education condition, according to the students' different grades, appose general history education and professional education from easy to difficult and from shallow to deep, giving play to the complementary advantages of both, so as to let student obtain a complete historical evolution.

\section{B. Update of teaching media}

It is obvious that traditional teaching media such as teachers' dictation, blackboard writing and multimedia show can hardly promote the teaching efficiency. It is very important for the innovation of architectural history education to have new teaching media to enhance the diversification of class forms and the vividness of knowledge teaching. New teaching media include the updating of teaching tools and updating of teaching methods. Of which, updating of teaching tool needs to depend on information technology to set up architectural history laboratory for virtual restoration of important historical figures, historical buildings, and historical scenario, so as to allow students to think creatively in the restored historical environment with learned textbook knowledge and fully understand the deep knowledge. In the process of simulating experience, the students' methods of receiving information extend to the senses of sight, touch and smell, which greatly deepen students' understanding of knowledge. Updating of teaching methods needs to cater to the diverse and opening demands, and strengthen international exchanges. The composition of students teaching team, teacher resources configuration, and flexibility of teaching environment should all be the updating object ${ }^{[7]}$. The same teaching group needs to have students from all over the world, and involve the participation of professional foreign teachers. According to the teaching arrangement, teaching team needs to conduct field research for thematic leaning and change teaching venues flexibly, at the same time, strengthen the communication with international famous schools, or refer to relevant successful experience.

\section{The strain of assessment mode}

Traditional evaluation mode is subject to usual performance in class and final course assignments. With the change of both teaching methods and teaching environment, the examination method is difficult to scientifically evaluate students' learning gains. In the new change, the grade level can remain the same. It usually is subject to a centesimal system, and divided into excellent (90-100), fine (80-89), good (70-79), qualified (60-69), unqualified $(<60)$ five levels. But the form of examination content can make some change. According to the characteristics of teaching methods, teaching plate and students' specialty, not overly consider the form of students' course, but pay attention to students' mastery of knowledge, allowing students to create their own expression of what they have learned. Take teacher group as a unit when evaluating homework, and examine the results of different forms of homework under the same standard. Such a way of assessment can give students the ability to combine their special talents with creativity to achieve the freedom of knowledge harvesting, and also maintain the students' diversity and the possibility of knowledge.

\section{CONCLUSION}

Taking the macroscopic background of the contemporary Chinese architectural education as the source, the above discussion analyzes the challenges that contemporary architectural history education faces, and the new demands on education target, education object, education mode in the new period, and puts forward the innovation strategy from the three aspects of positioning in architectural history education, teaching media and assessment of the existing problems and new demands. But it still needs to explore the detailed teaching methods, teaching contents, teaching links, etc. from more microcosmic aspects. It should combine with the actual teaching cases to demonstrate the scientific nature of innovation education.

The continuously developing science, technique and society demand architectural history education to keep innovating and seeking changes to adapt to the characteristics of the era and promote the development of architecture education. Contemporary Chinese architectural history education needs to absorb the world's advanced education idea and method, actively explore the education mode suitable for China's domestic construction personnel training requirements, and pursue featured architectural education system which advances with the era by combining the characteristics of the era, field and current situation.

\section{REFERENCES}

[1] Ding Wowo, Rethinking Chinese Architecture Education, Architectural Journal. pp. 14-16, 2004 (02).

[2] Zhong Dekun. Tu Sunan, New Development in New Period -- Chinese Architecture Education Rethinking, Architectural Journal. pp. 20-23, 2005 (12).

[3] Wu Nong, Fan Wenxiu, Analysis of Training of Foreign Architectural History Teacher Literacy, Higher Architecture Education. pp. 4-6, 2013 (03).

[4] ong Qiaohui. Li Yang, Research First, Practical Application - Foreign Architectural History Teaching Exploration and Research, Theoretical Research. pp. 76-78, 2017 (02).

[5] [5]Gwendolyn Wright. "History for Architects"- the History of History In American Schools Of Architecture, 1865-1975. 1990. 14, 25

[6] Liu Zhiyong, Zhang Xingguo, Du Chunlan, etc. Research on Experiential Teaching Method of Architectural History: Teaching Reform Lab Reform of Foreign Architectural History of Chongqing University, Higher Architecture Education, 2011(3) : 10-16.

[7] ROGER M. TARPY. Contemporary learning theory and research. New York: The McGraw-Hill Companies, Inc. 1997. 